\title{
ESTILOS FLUVIAIS NUM AMBIENTE SEMIÁRIDO, BACIA DO RIACHO DO SACO, PERNAMBUCO
}

\author{
Jonas Otaviano Praça de Souza ${ }^{1}$ \\ Ana Clara Magalhães de Barros ${ }^{2}$ \\ Antonio Carlos de Barros Correa ${ }^{3}$
}

\begin{abstract}
RESUMO - O crescimento da preocupação ambiental tem aumentado a necessidade de adoção de políticas de gestão de recursos hídricos. A compreensão das características e comportamento dos ambientes fluviais é essencial para uma gestão apropriada, em especial nos ambientes secos, primordialmente ambientes instáveis. $\mathrm{O}$ objetivo desta pesquisa procurou identificar e descrever os estilos fluviais da bacia do riacho do Saco, semiárido do Nordeste Brasileiro, e analisar o comportamento de cada estilo fluvial. Para tanto foram usados dados ASTER GDEM, imagens QUICKBIRD e dados de campo, para identificar os elementos e características dos estilos fluviais. Na bacia do riacho do Saco foram identificadas quatro unidades de paisagem: área de cabeceiras, zona inundável, escarpa de falha e pedimento; as características desses compartimentos irão controlar os estilos fluviais, conjuntamente com os impactos antrópicos. Foram identificados sete estilos fluviais, entre eles canais de voçoroca na área de cabeceira, desenvolvidos em colúvios quaternários; canal preenchido na zona inundável; canais encaixados na zona de escarpa de falha; canal rochoso com planície de inundação descontínua na área pedimentar. A partir da identificação e caracterização dos estilos fluviais, a adoção de uma política para gestão dos recursos hídricos torna-se mais adequada.
\end{abstract}

Palavras-chave: Estilos fluviais; classificação fluvial; ambiente semiárido; bacia do Riacho do Saco.

ABSTRACT - Fluvial styles in a Semi-Arid fluvial system, Riacho do Saco watershed, Pernambuco, northeastern Brazil. The growth of environmental aware-

Recebido: Abril 2013. Aceite: Dezembro 2015.

1 Professor Adjunto da Universidade Federal da Paraíba, Centro de Ciências Exatas e da Natureza, Departamento de Geociências, Cidade Universitária s/n, 58051-900, João Pessoa, Paraíba, Brasil. E-mail: jonasgeoufpe@yahoo.com.br

2 Doutoranda em Geografia, Programa de Pós-Graduação em Geografia da Universidade Federal de Pernambuco, Centro de Filosofia e Ciências Humanas, Departamento de Ciências Geográficas, Recife, Pernambuco, Brasil. E-mail: anaclarabarros@hotmail.com

3 Professor Adjunto da Universidade Federal de Pernambuco, Centro de Filosofia e Ciências Humanas, Departamento de Ciências Geográficas, Recife, Pernambuco, Brasil. E-mail: dbiase2001@terra.com.br 
ness has fostered the need for the adoption of public policies for the management of water resources. The understanding of the characteristics and behavior of fluvial environments is essential for an adequate management, especially in the prevailing unstable contexts of the drylands. According to these premises, this work aimed to identify and describe the fluvial styles of the Riacho do Saco watershed, within semi-arid Northeastern Brazil, as well as analyzing the behavior of each fluvial style individually. For this purpose, ASTER GDEM and QUICKBIRD imagery as well as field data were used in order to identify the elements and characteristics of the fluvial styles. Within the studied watershed, four landscape units were devised: headwaters zone, flood prone area, fault line escarpment and pediment. The traits of these units, coupled with human induced impacts, exert control upon the fluvial styles. In the study area seven fluvial styles were devised, such as: gully channels in the headwaters zone on Quaternary colluvium infills, cut-and-fill channels on flood prone areas, incised channels in the fault line escarpment and rocky bottom channel with discontinuous floodplains on the pediment. Based on the identification and characterization of these fluvial styles, the choice of adequate water resource management policies becomes more effective.

Keywords: Fluvial styles; fluvial classification; semi-arid environment; Saco Creek watershed.

RÉSUMÉ - Régimes fluviaux EN MILIEU SEMI-ARIDE : LE BASSIN DU RUISSEAU « Do SACo " (Pernambouc, BrÉsiL). Les préoccupations environnementales induisent le développement des politiques de gestion hydrique. Or, une gestion appropriée exige la bonne compréhension du comportement du milieu fluvial, surtout en climat aride et instable, comme c'est le cas du bassin du ruisseau « do Soco ». On y a décrit divers régimes fluviaux, à partir des données ASTER GDEM, des images QUICKBIRD et d’observations sur le terrain. On a identifié 4 unités de paysage : l'aire des sources, la zone inondable, l'escarpement de faille et le pédiment. Ce sont les caractéristiques de ces compartiments, associés aux impacts anthropiques, qui contrôlent les régimes d'écoulement. On a en distingué 7 types, dont les canaux de ravinement (voçorocas) dans la partie amont, ouverts dans les colluvions quaternaires, le canal ouvert dans l'aire inondable, les canaux mordant la zone de l'escarpement de faille, le canal rocheux avec plaine inondable discontinue, dans l'aire pédimentaire. Ces régime fluviaux ayant été identifiés et caractérisés, l'adoption d'une politique de gestion des ressources hydrauliques se trouve facilitée.

Mots clés: Régimes fluviaux; classification fluviale; milieu semi-aride.

\section{INTRODUÇÃO}

O semiárido brasileiro abarca uma extensão de cerca de $900 \mathrm{mil} \mathrm{km}^{2}$, concentrando-se no nordeste brasileiro e norte de minas, caracteriza-se pela irregularidade e concentração da chuva, o que em conjunto com temperaturas elevadas e altos índices de evapotranspiração gera grande déficit hídrico na maior parte do ano. Para lidar com o problema hídrico foi criada uma extensa rede de infraestruturas hídricas, baseada em grandes reservatórios para o abastecimento das comunidades urbanas e para grandes empreendi- 
mentos agrícolas e em inúmeras barragens rudimentares para o abastecimento das comunidades rurais (Vieira, 1996; Molinas, 1996; Campos, Vieira Neto \& Martins, 1997; Vieira, 2003; Cirilo et al., 2003).

Contudo, periodicamente, essa região sofre recorrentes problemas ambientais, potencializados por falhas na gestão da água, afetando principalmente as pequenas comunidades rurais, nos anos muito chuvosos, com rompimentos generalizados das barragens rudimentares e, nos anos secos, com falta de água. Um dos fatores para estas falhas é o pouco conhecimento que se tem do comportamento e das características dos rios do semiárido brasileiro. Pensando nisso, o presente trabalho tem como objetivo estudar as características e o comportamento fluvial de uma bacia representativa do semiárido brasileiro (ambiente seco em margem passiva), utilizando a proposta teórico-metodológica dos estilos fluviais (Brierley \& Fryirs, 2005), onde a partir da identificação e caracterização das unidades geomórficas é possível avaliar os processos e comportamento fluvial.

\section{CARACTERIZAÇÃO DA ÁREA DE ESTUDO}

A bacia de drenagem do riacho do Saco está situada na microrregião do Pajeú, Sertão Central de Pernambuco, entre os municípios de Serra Talhada, Triunfo e Santa Cruz da Baixa Verde, além dos municípios de Manaíra e São José da Princesa, na Paraíba (fig. 1), perfazendo uma área de $142,5 \mathrm{~km}^{2}$, sendo um afluente do rio Pajeú, um dos principais afluentes do rio São Francisco.

A bacia apresenta topografia irregular e amplitude altimétrica de cerca de 700 metros (fig. 1), tendo como principal componente a Serra da Baixa Verde, intrusão sienítica componente do Planalto da Borborema (Corrêa et al., 2010), o trecho próximo a jusante da bacia está inserido na Depressão Sertaneja. A diferença altimétrica influencia diretamente a precipitação e temperatura, onde em Serra Talhada (416m de altitude) apresenta em média $639 \mathrm{~mm} /$ ano de precipitação e temperatura média anual de $23,8^{\circ} \mathrm{C}$; enquanto Triunfo (1030m de altitude) tem em média $1230 \mathrm{~mm} /$ ano de precipitação e $21^{\circ} \mathrm{C}$ de temperatura média anual. As diferenças topográfica e climática definem quatro paisagens distintas: área de cabeceiras (acima de 900 metros), zona inundável (entre 800 e 900 metros em declividades entre $0 \%$ e $3 \%$ e que permanecem alagadas uma parte do ano), escarpa de falha (entre 600 e 800 metros com declividades acima de $45 \%$ ), e pedimento (região abaixo de 600 metros com algumas elevações isoladas). Assim, climaticamente, têm-se o pedimento com um clima semiárido; a área de cabeceira com um clima sub-úmido; e a escarpa de falha e a zona inundável com comportamento de precipitação e temperatura em transição entre o semiárido e o sub-úmido.

A diferença topoclimática reflete-se diretamente na vegetação e nos tipos de ocupação e uso do solo na bacia (fig. 1). A vegetação está diretamente ligada com a variação da precipitação, no pedimento a predominância é da vegetação de caatinga arbustiva (vegetação de tipo savana); na escarpa de falha há a transição entre a vegetação de caatinga arbustiva para caatinga arbórea, chegando a ter espécies da floresta subcaducifólia na 
zona inundável; e já na área de cabeceira há a predominância da floresta subcaducifólia. A ocupação e o uso do solo estão relacionados também com as diferenças ambientais da região, na zona semiárida a predominância de uso é a pecuária extensiva com a utilização do pasto nativo, e mais recentemente a agricultura irrigada e a piscicultura, atividades relacionadas com a Barragem do Saco, no centro da bacia. Já na área subúmida há um maior desenvolvimento da agricultura baseado em um complexo entre cana-de-açúcar e policultura, como feijão e milho. A intensidade maior na ocupação das áreas mais úmidas gerou uma maior remoção da vegetação nativa, restando apenas áreas de floresta subcaducifólia degradadas.

\section{ESTILOS FLUVIAIS}

Uma das propostas focadas no comportamento fluvial e com a gestão fluvial é o conceito de estilo fluvial, onde cada bacia hidrográfica é um conjunto próprio de atributos, analisados em três campos: pela planta do canal, pelas unidades geomórficas do canal fluvial e da planície de inundação, e pela textura do leito dos rios (Brierley \& Fryirs, 2005). A identificação e interpretação das unidades geomórficas possibilita a interpretação dos processos que refletem o comportamento dos estilos fluviais. Desta forma os estilos fluviais e seus padrões são avaliados em relação ao contexto paisagístico e às ligações espaciais e temporais dos seus processos geomorfológicos (Corrêa et al. 2009).

De uma forma sintética, a proposta teórica dos estilos fluviais registra o caráter e comportamento de um rio, oferecendo uma avaliação geomórfica dos seus padrões espaciais e evolutivos, a partir de uma análise focada na bacia de drenagem/hidrográfica (Corrêa et al., 2009). A análise das relações espaciais das unidades de paisagem, e de seus padrões de interconectividade fornecem uma base sobre a qual é possível interpretar a operação dos processos geomorfológicos em ação num determinado nível de resolução sistêmica. A perspectiva dos estilos fluviais dá ênfase às interações entre os elementos biofísicos, principalmente geomorfológicos, e apresenta uma metodologia para aplicação à gestão e recuperação fluvial (Fryirs \& Brierley, 2009). Para tanto fornece informações teórico-metodológicas visando a compreensão dos elementos fluviais, comportamento, evolução e condição ambiental, tendo como base o sistema fluvial (Brierley et al., 2002).

Os estilos fluviais podem ser identificados baseando-se nas características de três configurações de vales: vale confinado, sem a presença de planícies de inundação; vale semiconfinado ou parcialmente confinado, com a presença de planícies de inundação descontínuas; e não confinado ou vale de fundo aluvial, com a presença de planícies de inundação contínuas (Brierley et al., 2005). A análise sistemática das diferentes configurações de forma e processo, bem como as suas interações, em cada um dos tipos de vale mencionados, resulta na identificação dos estilos fluviais. Características locais podem ser levadas em consideração, ampliando os elementos analisados. 

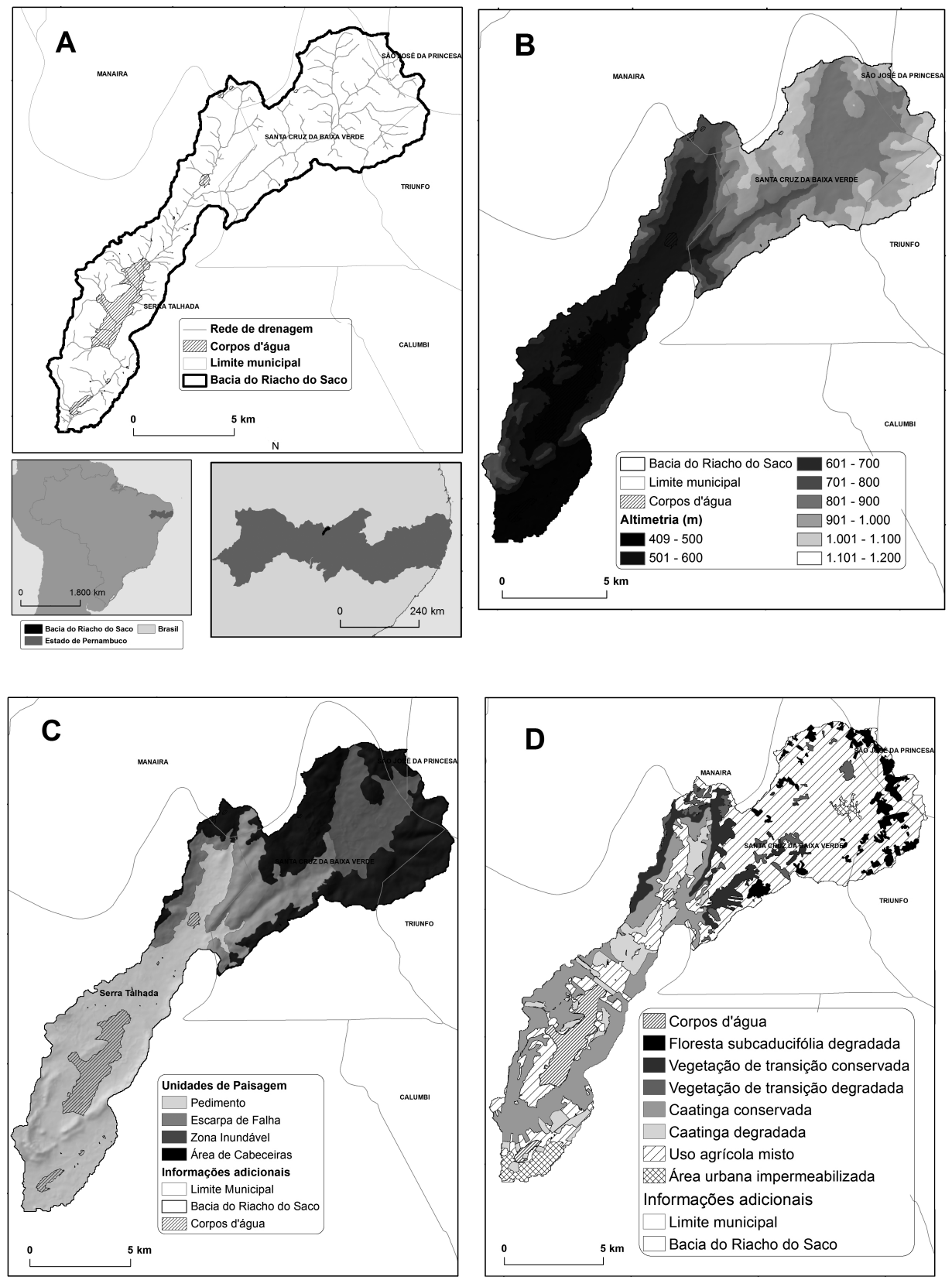

Sistema de coordenadas Geográficas DATUM: WGS 84

Fig. 1 - Bacia do riacho do Saco: Localização (A); Modelo Digital de Elevação (B);

Unidades de paisagem (C); ocupação do solo (D).

Fig. 1 - Saco creek watershed: Localization (A); Digital Elevation Model (B);

Landscape Units (C); Landcover (D). 
A partir destes procedimentos, a metodologia dos estilos fluviais oferece várias aplicações, tais como: programas de planeamento ambiental, observando a capacidade de ajuste do sistema e as possibilidades de modificação, podendo-se planear intervenções; conservação de estilos fluviais raros/ únicos, visando manter e valorizar a geodiversidade das paisagens fluviais; avaliação da condição geomórfica e do potencial de recuperação fluvial (Fryirs \& Brierley, 2009). Os estilos fluviais foram inicialmente aplicados às bacias costeiras de New South Wales - Austrália (Brierley et al., 2002), tendo sido identificados 21 estilos fluviais diferentes. No Brasil, algumas pesquisas aplicaram a ideia de estilos fluviais, sendo que num dos estudos realizou-se uma análise experimental numa bacia semiárida, o que resultou na identificação de dois estilos fluviais diferentes, e introduziu formas e processos de origem especificamente antrópica à análise (Corrêa et al., 2009; Souza \& Corrêa, 2012; Peixoto et al., 2010; Oliveira, 2010).

\section{MATERIAIS E MÉTODOS}

Para caracterizar e mapear os estilos fluviais são necessárias informações sobre a morfologia do canal fluvial, as unidades geomórficas que compõem o ambiente fluvial (do canal e da planície de inundação), as características sedimentares, o regime de fluxo e a vegetação ripária (Brierley \& Fryirs, 2000). Será seguida a metodologia indicada por Brierley \& Fryirs (2005), utilizando algumas adaptações, tais como a introdução de elementos antrópicos na identificação dos estilos fluviais, em especial nas matrizes de informação para cada estilo fluvial (Corrêa, Maciel, Souza, Azambuja \& Araújo, 2009; Souza \& Corrêa, 2012). No geral, para o mapeamento dos estilos fluviais serão utilizados os mapeamentos já apresentados: modelo digital de elevação, unidades de paisagem e uso do solo. Também serão usadas imagens QUICKBIRD, além de informações obtidas no campo com o uso de GPS (GPS Garmim Etrex VistaHcx, e o GPS topográfico PRO-XH - Trimble).

O primeiro passo é a definição do tipo do vale para cada trecho do canal, o que pode ser realizado a partir da identificação da presença, ou não, de planícies de inundação ao longo de cada rio, visto que as planícies são geradas a partir do extravasamento do fluxo do canal, comportamento preponderante na classificação de tipos de vale. $\mathrm{O}$ tipo de vale pode ser: confinado, com menos de $10 \%$ do trecho com planície de inundação; parcialmente confinado, entre 10\% e 90\% do trecho com planície de inundação; e não confinado (ou vale aluvial), mais de $90 \%$ do trecho apresentando planície de inundação (Brierley \& Fryirs, 2005).

Após a definição dos tipos de vale, observa-se o número de canais, a geometria dos canais, grau de sinuosidade, estabilidade das margens, as unidades geomórficas dos canais e das planícies de inundação, e a textura do material do leito.

Para cada estilo fluvial identificado será escolhido um trecho representativo, do qual será construída uma matriz de informação e um mapa morfológico para aquele estilo fluvial (escala maior que 1:6 000). Os mapas morfológicos apresentam as margens do fundo de vale, os canais, as planícies de inundação, as unidades geomórficas (no canal e na planície), a vegetação associada (no canal e na planície) e as alterações antrópicas. 
A matriz de informação terá como base inicial as informações obtidas a partir do mapeamento morfológico, com informações sobre as características/elementos do trecho, comportamento fluvial do trecho e controles ambientais gerais. Ou seja, após identificar as características gerais da bacia, assinalaram-se os compartimentos de relevo e suas características, e os estilos fluviais presentes (como colocado anteriormente); para cada estilo foi identificada a configuração do vale; a assembleia de unidades geomórficas existentes e suas características; a forma em planta do estilo; e a textura do material do leito. Após a identificação das características do estilo foi possível interpretar o comportamento do rio, avaliando-o em três estágios: baixa, média e alta vazão. Por fim, foram definidos os controles fluviais, que serão as condições limite para cada estilo fluvial, tais como: bacia a montante, unidade de paisagem, zona processual, morfologia e declividade do vale, competência do fluxo e intervenções antrópicas (Brierley \& Fryirs, 2005).

\section{RESULTADOS}

Para a bacia do riacho do Saco foram encontrados sete tipos de estilos fluviais, sendo mapeada a incidência em trechos de cada um dos tipos (fig. 2): Cabeceira de Drenagem (fig. 3), Canal em Garganta (fig. 4), Canal Entalhado em Voçoroca (fig. 5), Canal Rochoso

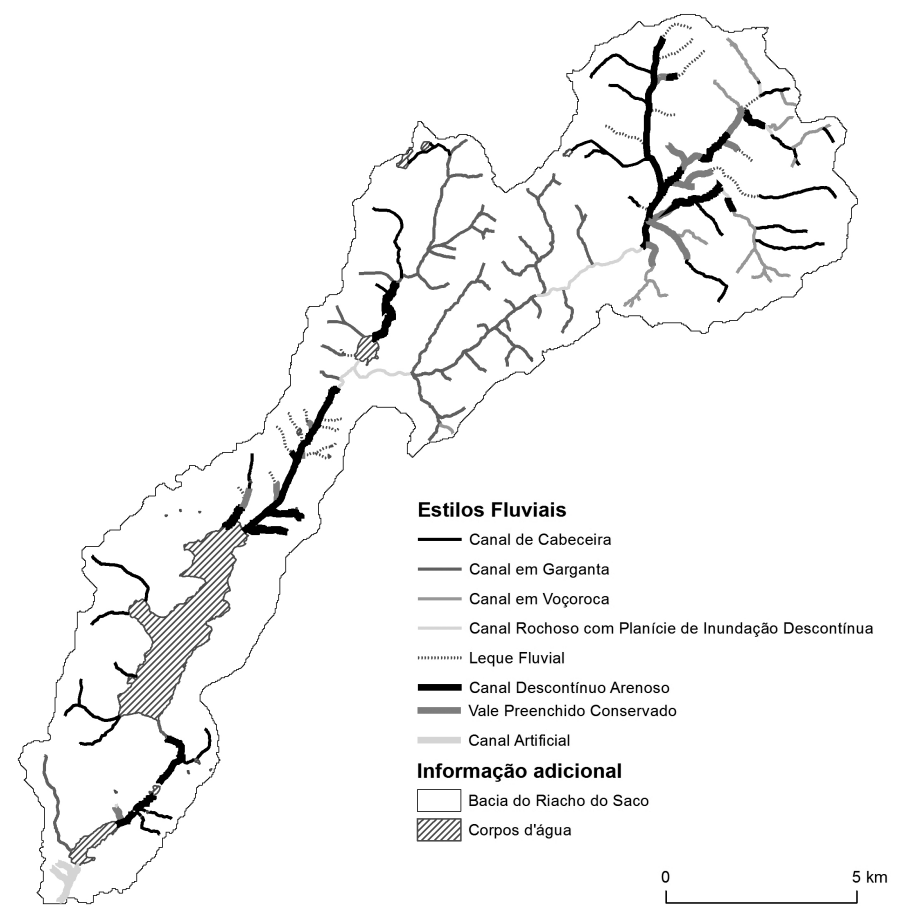

Fig. 2 - Estilos Fluviais da bacia do Riacho do Saco.

Fig. 2 - River Styles of Saco basin. 
com Planície Descontínua (fig. 6), Leque Fluvial (fig. 7), Canal Arenoso Descontínuo (fig. 8) e Vale Preenchido Conservado (fig. 9). Além desses estilos, foram identificados alguns trechos, especialmente os inseridos na área urbana da cidade de Serra Talhada onde os canais apresentam modificações generalizadas, sendo que alguns trechos foram suprimidos, onde o escoamento será controlado pela drenagem urbana artificial. Dessa forma, apesar de serem mapeados eles não serão analisados.

O quadro I, organiza e sumariza os estilos fluviais encontrados bem como as características gerais de cada um deles, avaliando suas participações percentuais em relação ao tamanho total dos canais da bacia, a distribuição em relação às unidades de paisagem, o tipo de vale de cada estilo, além da predominância do material do leito para cada estilo.

Quadro I - Sumário dos Estilos Fluviais da bacia do riacho do Saco.

Table I - Summary of River Styles of Saco creek watershed.

\begin{tabular}{|c|c|c|c|c|}
\hline Estilo Fluvial & Distribuição & $\begin{array}{c}\text { Unidades } \\
\text { de Paisagem }\end{array}$ & $\begin{array}{c}\text { Tipo } \\
\text { de Vale }\end{array}$ & $\begin{array}{c}\text { Material } \\
\text { do leito }\end{array}$ \\
\hline Canal de Cabeceira & $32,9 \%$ & Área de Cabeceira & Confinado & $\begin{array}{l}\text { Cascalho e } \\
\text { Matacões }\end{array}$ \\
\hline Canal em Voçoroca & $9,4 \%$ & Área de Cabeceira & Confinado & Areia \\
\hline Canal em Garganta & $19,5 \%$ & Escarpa de Falha & Confinado & Matacões \\
\hline Leque Fluvial & $9,1 \%$ & $\begin{array}{l}\text { Zona Inundável } \\
\text { e Pedimento }\end{array}$ & Aluvial & Areia \\
\hline Vale Preenchido Conservado & $6,5 \%$ & Zona Inundável & Aluvial & Silte-Argila \\
\hline Canal Descontínuo Arenoso & $15,6 \%$ & $\begin{array}{l}\text { Zona Inundável } \\
\text { e Pedimento }\end{array}$ & Aluvial & $\begin{array}{l}\text { Areia-Silte- } \\
\text {-Argila }\end{array}$ \\
\hline Canal Rochoso com Planície Descontínua & $5,2 \%$ & Áreas de transição & $\begin{array}{c}\text { Parcialmente } \\
\text { Confinado }\end{array}$ & Cascalho \\
\hline Canais artificiais & $1,8 \%$ & - & Confinado & - \\
\hline
\end{tabular}

Para cada estilo fluvial foi escolhido um trecho que apresentasse todas as características representativas do estilo, e para cada um desses trechos foi realizado um mapeamento de detalhe das formas fluviais, uma matriz de informação e imagens da área. Para a matriz de informação, foram realizadas algumas modificações visando adequar a metodologia à área estudada, o comportamento do rio foi dividido em baixa, média e alta vazão; onde a baixa vazão é no período seco do ano, a alta vazão é durante os eventos chuvosos fortes e algumas horas após esses eventos, quando as vazões atingem seus picos; e a média vazão é durante os meses chuvosos, mas nos momentos que não há chuva ou impacto direto de uma chuva anterior.

Os trechos classificados como Cabeceira de Drenagem situam-se em canais de baixa ordem, com leito rochoso, baixa sinuosidade e controle erosivo para sua evolução. Não apresentam extravasamento do fluxo, sendo confinado com margens estáveis controladas pela litologia. Apresenta gradiente médio ou alto no perfil longitudinal e declividade média nas encostas. Os principais elementos encontrados nesse tipo de canal são sequên- 
cia de corredeiras, poças e matacões (boulder); apresentando também, secundariamente, barras arenosas normalmente associadas com detritos de vegetação. Situam-se nas principais áreas fonte dos sedimentos, não apresentando fluxo na baixa vazão (em alguns canais pode haver fluxo resultado de nascentes) e podendo transportar blocos na alta vazão, a partir de eventos extremos, contudo devido ao gradiente do canal somado com as declividades da encosta não há extravasamento do fluxo. Em alguns pontos mais planos há plantio de cana-de-açúcar e a construção de poços rasos (localmente chamados de poços amazonas), contudo esses trechos apresentam baixo impacto antrópico na estrutura e comportamento fluvial, apenas algumas pequenas barragens temporárias causam maior impacto.

Os Canais em Garganta estão localizados na unidade de paisagem escarpa de falha, apresentando vales estreitos entalhados em linhas de fraqueza, com margens estáveis com controles estruturais. Apresentam gradiente alto no perfil longitudinal, com a presença de vários knickpoints e encostas, também, com alta declividade. Têm como principais unidades no canal, cachoeiras, sequência de cascatas e poças, e matacões, possivelmente de origem coluvial.

Na baixa vazão não há fluxo nos Canais de Garganta, mas é possível a presença de água acumulada nas poças, enquanto que na alta vazão o fluxo apresenta alta capacidade e competência de transporte, retirando todo o material detrítico acumulado. Devido à alta declividade da área as intervenções humanas são praticamente inexistentes.

Nas regiões acima dos 900 metros, com densa cobertura coluvial Quaternária, desenvolveu-se uma rede de voçorocas, algumas das quais comportam-se como canais fluviais; estes trechos estão diretamente ligados à retirada da vegetação nativa para o uso agrícola. Deste modo, esses trechos apresentam perfis longitudinais com gradiente médio ou baixo, e perfis transversais com média declividade; canais estreitos e com alta dissecação, com margens e leitos instáveis com predominância de texturas cascalho-arenosas, apresentando erosão de subsuperfície nas margens e voçorocas laterais.

Na baixa vazão não há presença de água, e na alta vazão apresenta grande capacidade e competência de transporte, como também alta taxa de erosão lateral e vertical, sendo uma grande fonte de sedimentos para os trechos a jusante. Em alguns pontos há intervenções antrópicas visando diminuir a erosão como terraceamento e a construção de barragens de sedimentos.

Os Canais Rochosos com Planície de Inundação Descontínua apresentam baixa incidência na bacia, normalmente em áreas de transição entre trechos com alta capacidade de transporte e trechos com baixa capacidade de transporte, ou vice-versa. São caracterizados pela sinuosidade média, encostas suaves e gradiente baixo, fatores que geram erosão nas margens côncavas e extravasamento do fluxo nas margens convexas, formando planícies de inundação descontínuas. Na baixa vazão não há fluxo e nas altas vazões há o extravasamento do fluxo, e a retirada dos sedimentos presentes no leito rochoso. Nesses trechos o principal impacto antrópico é a presença de pontes, normalmente no mesmo nível das altas vazões. 


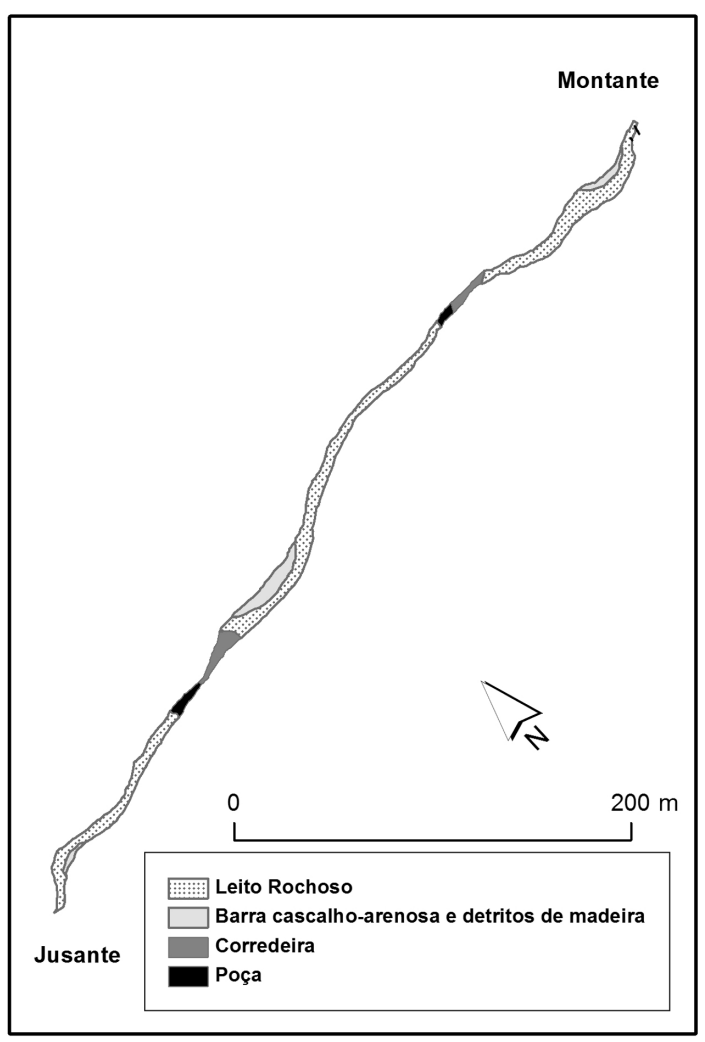

Sistema de Coordenada Geográfica
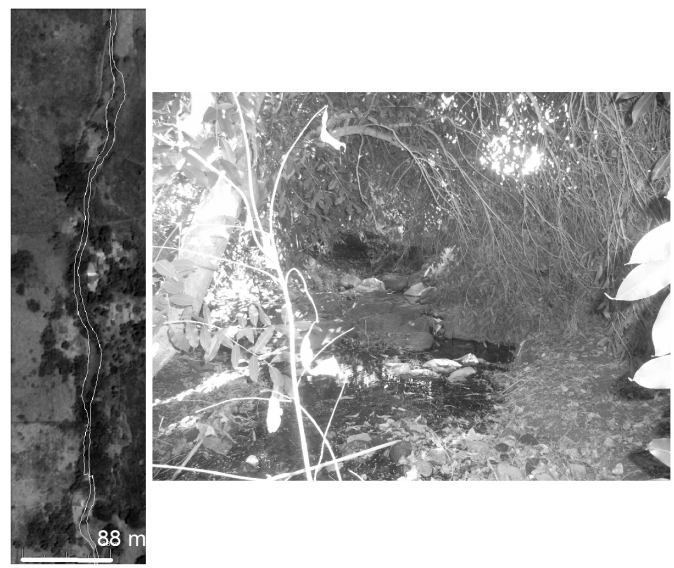

\begin{tabular}{l|l}
\multicolumn{2}{c}{ MATRIZ DE ESTILOS FLUVIAIS - CANAIS DE } \\
CABECEIRA
\end{tabular}

- Blocos rochosos: blocos soltos distribuídos no leito rochoso, podendo ter sido transportados ou gerados in locu

- Pequenas corredeiras e poças: nos pontos com aumento de gradiente nos canais há a presença de pequenas sequências de corredeiras e poças.

- Barras cascalho-arenosas: formadas a partir de concentração de sedimentos em irregularidades da margem e em conjunto com alterações antrópicas como poços amazonas e barramentos temporários (antrópicos ou por detritos de madeira).

- Canais secundários: canais de cabeceira canais de voçoroca.

\begin{tabular}{l|l}
\hline Vegetação & $\begin{array}{l}\text { Detritos de Vegetação, e margens com } \\
\text { vegetação ripária, tanto nativa como exótica. }\end{array}$
\end{tabular}

\begin{tabular}{c|c} 
Associada & vegetação ripária, tanto nativa como exótica. \\
\hline COMPORTAMENTO DO RIO
\end{tabular}

Baixa Vazão Ausência de Fluxo, em alguns pontos há a presença de nascentes semiperenes.

\begin{tabular}{l|l}
\hline Média Vazão & Presença de fluxo preenchendo o canal, com
\end{tabular} transporte de cascalhos, mas sem transporte de blocos e grandes detritos de madeira.

\begin{tabular}{l|l}
\hline Alta Vazão & $\begin{array}{l}\text { Fluxo turbulento realizando a lavagem de } \\
\text { sedimento mais finos (cascalho/areia) e a } \\
\text { movimentação dos blocos e dos detritos de } \\
\text { madeira maiores }\end{array}$
\end{tabular}

\begin{tabular}{|c|c|}
\hline \multicolumn{2}{|r|}{ CONTROLES } \\
\hline $\begin{array}{l}\text { Bacia a } \\
\text { Montante }\end{array}$ & Áreas de cimeira \\
\hline $\begin{array}{l}\text { Unidade de } \\
\text { Paisagem }\end{array}$ & $\begin{array}{l}\text { Cimeiras, cabeceiras de drenagem, drenagem } \\
\text { de primeira ou segunda ordem }\end{array}$ \\
\hline $\begin{array}{l}\text { Zona } \\
\text { Processual }\end{array}$ & Zona de produção de sedimento. \\
\hline $\begin{array}{l}\text { Morfologia } \\
\text { do Vale }\end{array}$ & $\begin{array}{l}\text { Vale em V,com encostas adjacentes com } \\
\text { declividades média para alta. Controle erosivo. }\end{array}$ \\
\hline $\begin{array}{l}\text { Declive do } \\
\text { Vale }\end{array}$ & Gradiente médio. \\
\hline $\begin{array}{l}\text { Competência } \\
\text { do fluxo }\end{array}$ & $\begin{array}{l}\text { Na alta vazão há o transporte de blocos - } 30 \\
\text { cm de eixo }\end{array}$ \\
\hline $\begin{array}{l}\text { Intervenção } \\
\text { Antrópica }\end{array}$ & $\begin{array}{l}\text { Agricultura nas encostas mais planas, poços } \\
\text { amazonas próximos as barras arenosas, e nas } \\
\text { encostas de baixa declividade com colúvio. } \\
\text { Em alguns pontos há o barramento intencional } \\
\text { do canal. }\end{array}$ \\
\hline
\end{tabular}

Fig. 3 - Estilo Fluvial Canal de Cabeceira Estrutural.

Fig. 3 - Headwater Channel River Style. 


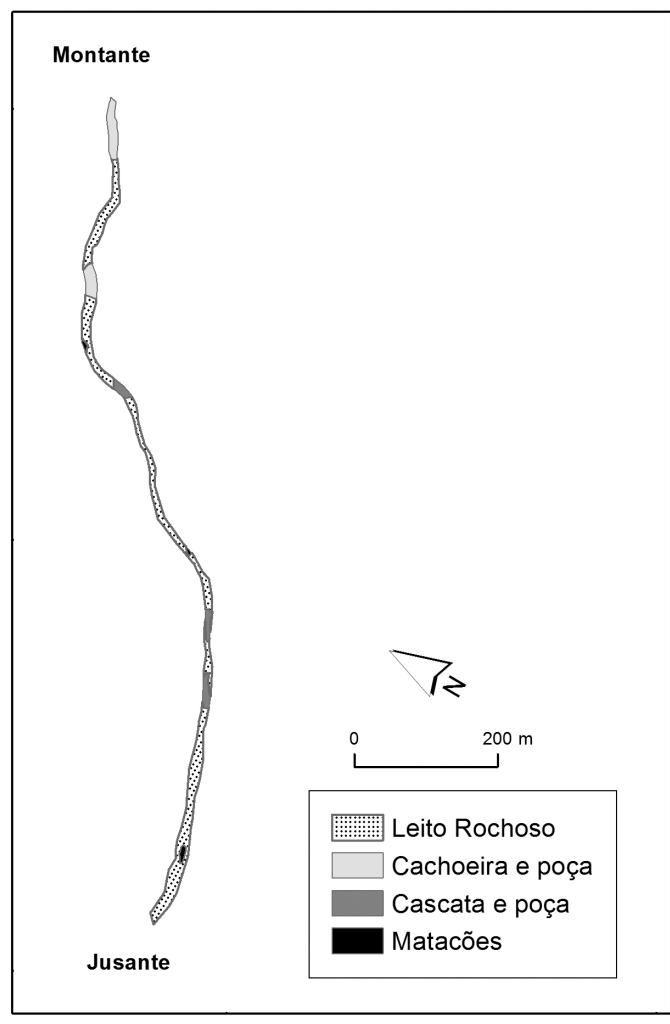

\begin{tabular}{l|l}
\multicolumn{2}{c}{ MATRIZ DE ESTILOS FLUVIAIS - CANAL EM } \\
GARGANTA
\end{tabular}

Associada

\begin{tabular}{|c|c|}
\hline \multicolumn{2}{|r|}{ COMPORTAMENTO DO RIO } \\
\hline Baixa Vazão & $\begin{array}{l}\text { Ausência de fluxo e acumulo de água nas áreas } \\
\text { de poças. }\end{array}$ \\
\hline Média Vazão & $\begin{array}{l}\text { Presença de fluxo no canal, nas áreas de matacões } \\
\text { formando cascatas o fluxo dá-se a partir dos } \\
\text { espaços entre os matacões. }\end{array}$ \\
\hline Alta Vazão & $\begin{array}{l}\text { Fluxo preenchendo todo fundo do vale, passando } \\
\text { sobre os matacões das áreas de cascata, } \\
\text { remobilizando os sedimentos presentes nas poças, } \\
\text { e eventos extremos pode haver o deslocamento de } \\
\text { matacões. }\end{array}$ \\
\hline \multicolumn{2}{|r|}{ CONTROLES } \\
\hline $\begin{array}{l}\text { Bacia a } \\
\text { Montante }\end{array}$ & $\begin{array}{l}\text { Áreas planas soerguidas ou cabeceiras de } \\
\text { drenagem ingreme com controle estrutural. }\end{array}$ \\
\hline $\begin{array}{l}\text { Unidade de } \\
\text { Paisagem }\end{array}$ & Zona de escarpa de falha, controle estrutural. \\
\hline $\begin{array}{l}\text { Zona } \\
\text { Processual }\end{array}$ & Zona de transporte. \\
\hline $\begin{array}{l}\text { Morfologia do } \\
\text { Vale }\end{array}$ & $\begin{array}{l}\text { Vales estreitos, encaixados em linhas de fraqueza } \\
\text { com encostas ingremes. }\end{array}$ \\
\hline $\begin{array}{l}\text { Declive do } \\
\text { Vale }\end{array}$ & Alto gradiente. \\
\hline $\begin{array}{l}\text { Competência } \\
\text { do fluxo }\end{array}$ & $\begin{array}{l}\text { Alta competência de transporte. Podendo em } \\
\text { eventos extremos mover matacões. }\end{array}$ \\
\hline $\begin{array}{l}\text { Intervenção } \\
\text { Antrópica }\end{array}$ & $\begin{array}{l}\text { Devido a alta declividade do canal e das encostas } \\
\text { não é comum a utilização das áreas. Com exceção } \\
\text { de algumas áreas mais altas utilizadas no plantio } \\
\text { de cana de açúcar. }\end{array}$ \\
\hline
\end{tabular}

Fig. 4 - Estilo fluvial Canal em Garganta.

Fig. 4 - Gorge Channel River Style. 


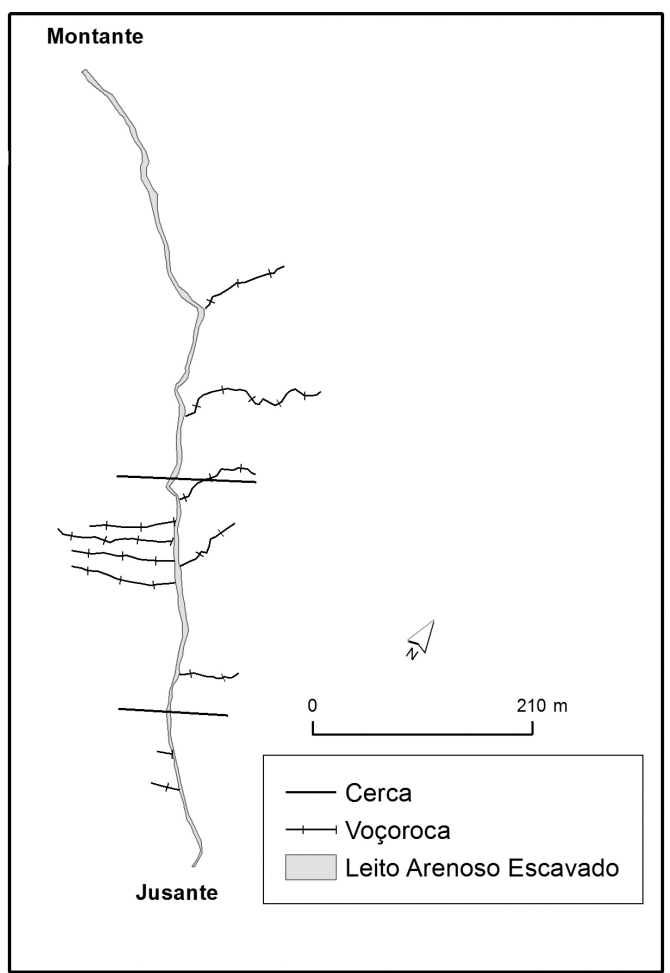

DATurdenada Geográfica DATUM: WGS 84

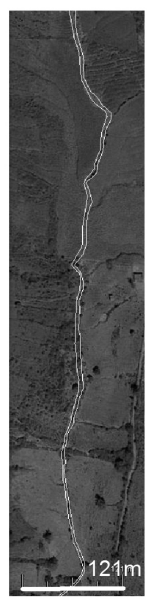

\begin{tabular}{|c|c|}
\hline \multicolumn{2}{|c|}{$\begin{array}{l}\text { MATRIZ DE ESTILOS FLUVIAIS - CANAL EM } \\
\text { VOÇOROCA }\end{array}$} \\
\hline \multicolumn{2}{|r|}{ CARACTERISTICAS FLUVIAIS } \\
\hline $\begin{array}{l}\text { Configuração } \\
\text { do Vale }\end{array}$ & Confinado \\
\hline $\begin{array}{l}\text { Configuração } \\
\text { do canal }\end{array}$ & $\begin{array}{l}\text { Canal irregular, com canal dissecando } \\
\text { colúvios quaternário, fluxo concentrado na } \\
\text { incisão do canal. }\end{array}$ \\
\hline $\begin{array}{l}\text { Textura de } \\
\text { Materiais de } \\
\text { Leito }\end{array}$ & $\begin{array}{l}\text { Leito cascalho-arenoso e presença de } \\
\text { detritos de madeira e blocos. }\end{array}$ \\
\hline $\begin{array}{l}\text { Unidades } \\
\text { Geomórficas }\end{array}$ & $\begin{array}{l}\text { Geometria do Canal: canal irregular estreito } \\
\text { (máximo } 5 \text { metros) com alta dissecação. } \\
\text { Margens ingremes sujeitas } \\
\text { desbarrancamento. }\end{array}$ \\
\hline & Formas associadas ao canal: \\
\hline
\end{tabular}

- Pipes: canais de erosão subsuperficial, aumentando a instabilidade lateral.

- Voçorocas laterais: rede de voçorocas curtas diretamente ligadas ao canal e que fornecem sedimento e água para o fluxo principal.

Vegetação Normalmente associado a áreas onde há a

Associada retirada da vegetação nativa, para o plantio de pasto e/ou cana-de-açúcar. Há a possibilidade do crescimento de vegetação em algumas áreas do canal, como a acreção de detritos de madeira a partir da expansão das margens.

\section{COMPORTAMENTO DO RIO}

Baixa Vazão Ausência de fluxo.

Média Vazão Presença de água em subsuperfície e em depressões no leito.

Alta Vazão Presença de fluxo turbulento, com alta taxa de transporte e erosão tanto lateral quanto vertical.

\begin{tabular}{|c|c|}
\hline \multicolumn{2}{|r|}{ CONTROLES } \\
\hline $\begin{array}{l}\text { Bacia a } \\
\text { Montante }\end{array}$ & Presente em áreas de cabeceira. \\
\hline $\begin{array}{l}\text { Unidade de } \\
\text { Paisagem }\end{array}$ & $\begin{array}{l}\text { Áreas soerguidas e/ou de cimeira com } \\
\text { presença de espessos colúvios quaternários. }\end{array}$ \\
\hline $\begin{array}{l}\text { Zona } \\
\text { Processual }\end{array}$ & Zona de produção de sedimentos. \\
\hline $\begin{array}{l}\text { Morfologia } \\
\text { do Vale }\end{array}$ & $\begin{array}{l}\text { Vales estreitos com declividade média, } \\
\text { preenchidos por sedimento quaternário. }\end{array}$ \\
\hline $\begin{array}{l}\text { Declive do } \\
\text { Vale }\end{array}$ & Gradiente médio. \\
\hline $\begin{array}{l}\text { Competência } \\
\text { do fluxo }\end{array}$ & $\begin{array}{l}\text { Alta competência de transporte, sendo capaz } \\
\text { de transportar toda a granulometria } \\
\text { disponível de sedimento, gerando erosão } \\
\text { lateral e vertical. }\end{array}$ \\
\hline $\begin{array}{l}\text { Intervenção } \\
\text { Antrópica }\end{array}$ & $\begin{array}{l}\text { Retirada da vegetação das encostas e } \\
\text { plantação de cana-de-açúcar e pasto, } \\
\text { delimitação dos terrenos com cercas. Em } \\
\text { alguns pontos há intervenções na tentativa de } \\
\text { diminuir a taxa de erosão, como } \\
\text { terraceamento e barragens de sedimento. }\end{array}$ \\
\hline
\end{tabular}

Fig. 5 - Estilo fluvial Canal em Voçoroca.

Fig. 5 - Gully Channel River Style. 

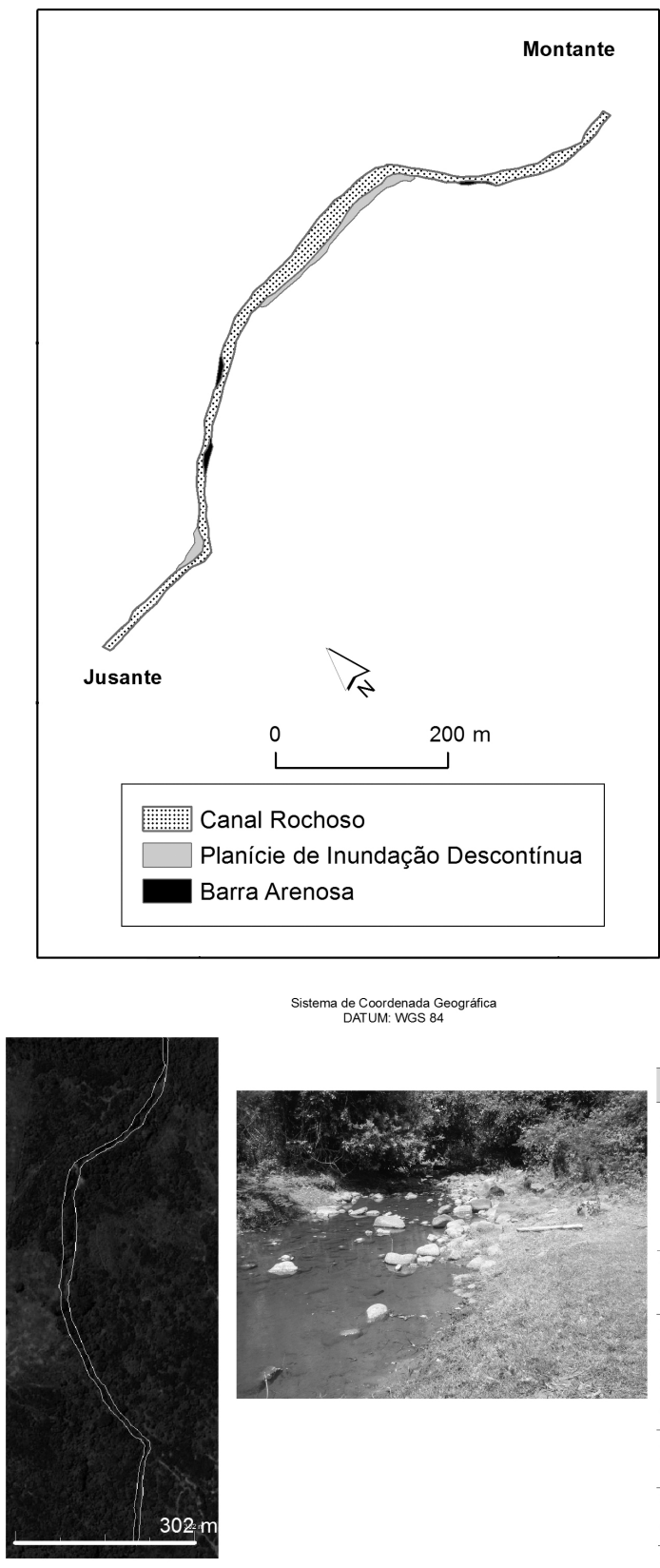

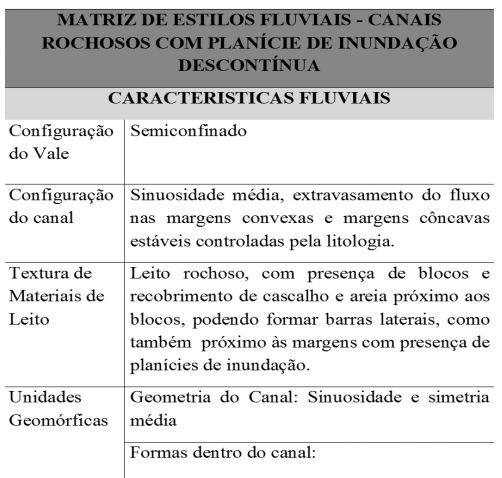

- Blocos rochosos: blocos soltos distribuídos no leito rochoso, transportado de trechos com maior gradiente a montante ou da encosta.

- Barras arenosas: barras laterais nos trechos de menor sinuosidade, com predominância de areia grossa. Formas fora do canal:

- Planície de inundação descontínua: textura areno-lamosa, dispostas em forma de bolsões nas margem convexas do canal. Vegetação Detritos de vegetação, vegetação ripária de Associada maneira geral conservada. Presença de vegetação herbácea e arbustiva nas planícies de inundação.

\section{COMPORTAMENTO DO RIO}

\section{Baixa Vazão Ausência de fluxo.}

Média Vazão Presença de fluxo preenchendo o canal, com transporte de sedimentos finos, sedimentos grosseiros permanecem presos nas irregularidades do leito rochoso e próximo aos blocos.

\begin{tabular}{l|l}
\hline Alta Vazão & $\begin{array}{l}\text { Fluxo turbulento realizando a lavagem de } \\
\text { sedimento (cascalho/areia), extravasamento do } \\
\text { fluxo e deposição de sedimentos nas áreas de } \\
\text { planície de inundação. Pode haver } \\
\text { deslocamento dos blocos }\end{array}$
\end{tabular}

\section{CONTROLES}

\begin{tabular}{|c|c|}
\hline $\begin{array}{l}\text { Bacia a } \\
\text { Montante }\end{array}$ & $\begin{array}{l}\text { Pode haver duas configurações a montante para } \\
\text { este estilo, a primeira são áreas com alta } \\
\text { declividade (escarpas) ou áreas de retenção de } \\
\text { sedimento, neste caso com o aumento da } \\
\text { declividade o sedimento é retirado em grande } \\
\text { parte. }\end{array}$ \\
\hline $\begin{array}{l}\text { Unidade de } \\
\text { Paisagem }\end{array}$ & $\begin{array}{l}\text { Áreas de transição com características } \\
\text { pedimentares. }\end{array}$ \\
\hline $\begin{array}{l}\text { Zona } \\
\text { Processual } \\
\text { Morfologia } \\
\text { do Vale }\end{array}$ & $\begin{array}{l}\text { Zona de transporte de sedimento - transporte } \\
\text { de fundo } \\
\text { Vales com encostas suaves, com sinuosidade } \\
\text { média. }\end{array}$ \\
\hline $\begin{array}{l}\text { Declive do } \\
\text { Vale }\end{array}$ & Baixo gradiente. \\
\hline $\begin{array}{l}\text { Competência } \\
\text { do fluxo }\end{array}$ & $\begin{array}{l}\text { Na alta vazão há a lavagem da areia e cascalho } \\
\text { e o deslocamento dos blocos. }\end{array}$ \\
\hline $\begin{array}{l}\text { Intervenção } \\
\text { Antrópica }\end{array}$ & $\begin{array}{l}\text { Não apresenta uso direto da área aluvial, } \\
\text { apenas a presença de algumas pontes, } \\
\text { normalmente situadas acima do nível de alta } \\
\text { vazão. }\end{array}$ \\
\hline
\end{tabular}




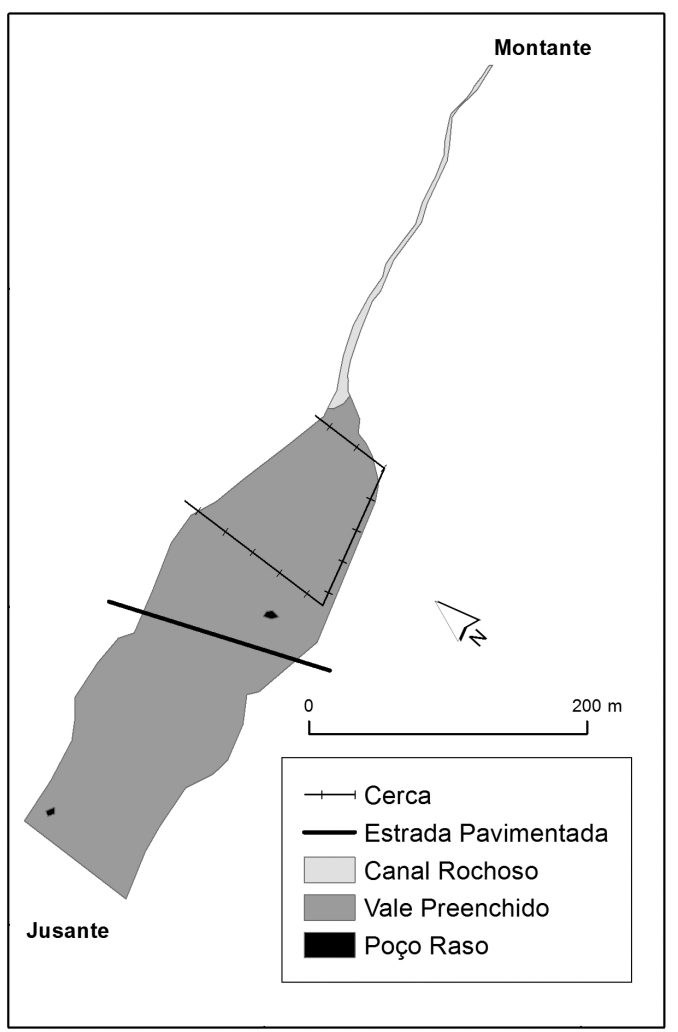

Sistema de Coordenada Geográfica DATUM. WGS 84
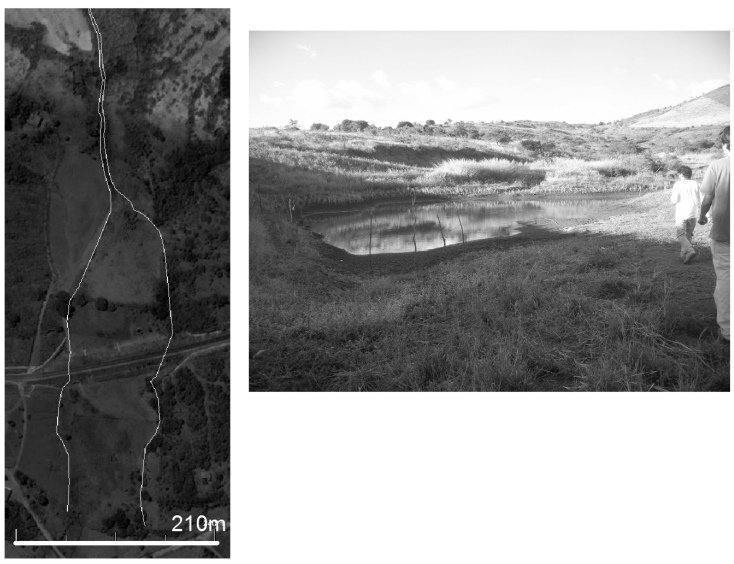

\begin{tabular}{l} 
MATRIZ DE ESTILOS FLUVIAIS - LEQUE \\
FLUVIAL \\
CARACTERISTICAS FLUVIAIS \\
\hline CORfigurã̃o Trañão entre vale estreito confinado para
\end{tabular}

Configuração Transição entre vale estreito confinado para \begin{tabular}{l|l} 
do Vale & vale não confinado.
\end{tabular}

Configuração Canal retilíneo regular, extravasando em do canal canal não definido.

\begin{tabular}{l|l}
\hline Textura de & Textura variada, material grosseiro no trecho
\end{tabular} Materiais de confinado e material fino no fim do trecho Leito não confinado.

Unidades Geometria do Canal: Irregular, inicialmente

Geomórficas estreito e confinado, posteriormente não há canal definido.

Formas associadas ao vale:

- Fundo de vale preenchido: planície de inundação preenche toda área do vale, com textura predominantemente argiloarenosa.

- Pode haver outras unidades relacionadas aos Canais de Cabeceira e/ou as aos Vales Preenchidos Conservados.

Vegetação Vegetação ripária geralmente conservada no Associada trechos confinado, e plantações dentro do vale no trecho não confinado, pasto e canade-açúcar.

\section{COMPORTAMENTO DO RIO}

Baixa Vazão Ausência de fluxo, presença de água em subsuperfície e depressões na área não confinada.

Média Vazão Saturação da planície de inundação e nível máximo de água nas depressões. O fluxo ocorre em subsuperfície e no trecho de leito rochoso.

Alta Vazão O fluxo retira todo o sedimento do leito rochoso, na área não confinada o fluxo de água corre acima do nível de sedimentação da planície, preenchendo todo o vale, e em eventos extremos remobilizando os sedimentos da planície.

\begin{tabular}{l|l}
\hline \multicolumn{2}{c}{ CONTROLES } \\
\hline $\begin{array}{l}\text { Bacia a } \\
\text { Montante }\end{array}$ & $\begin{array}{l}\text { Áreas de cabeceira, normalmente em áreas } \\
\text { com forte variação de declividade. }\end{array}$ \\
\hline $\begin{array}{l}\text { Unidade de } \\
\text { Paisagem }\end{array}$ & $\begin{array}{l}\text { Base de encostas, e/ou anterior a áreas } \\
\text { planas. } \\
\text { Zona }\end{array}$ \\
$\begin{array}{l}\text { Processual de transporte e acumulação de } \\
\text { sedimentos. }\end{array}$ \\
\hline $\begin{array}{l}\text { Morfologia } \\
\text { do Vale }\end{array}$ & $\begin{array}{l}\text { Vales estreitos comalta declividade até vales } \\
\text { largos com baixa declividade. }\end{array}$ \\
\hline $\begin{array}{l}\text { Declive do } \\
\text { Vale }\end{array}$ & $\begin{array}{l}\text { Média/alta declividade para o trecho } \\
\text { confinado com mudança brusca para baixa } \\
\text { declividade do trecho não confinado. }\end{array}$ \\
\hline $\begin{array}{l}\text { Competência } \\
\text { do fluxo }\end{array}$ & $\begin{array}{l}\text { Competência média até o trecho não } \\
\text { confinado, onde a competência diminui } \\
\text { drasticamente. }\end{array}$ \\
\hline $\begin{array}{l}\text { Intervenção } \\
\text { Antrópica }\end{array}$ & $\begin{array}{l}\text { Retirada da vegetação do vale, plantio de } \\
\text { pasto e cana-de-açúcar, instalação de poços } \\
\text { amazonas. Presença de estradas não } \\
\text { pavimentadas cortando o vale, como } \\
\text { também pontes de estradas pavimentadas. }\end{array}$ \\
\hline
\end{tabular}

Fig. 7 - Estilo fluvial de Leque Fluvial.

Fig. 7 - Floodout River Style. 


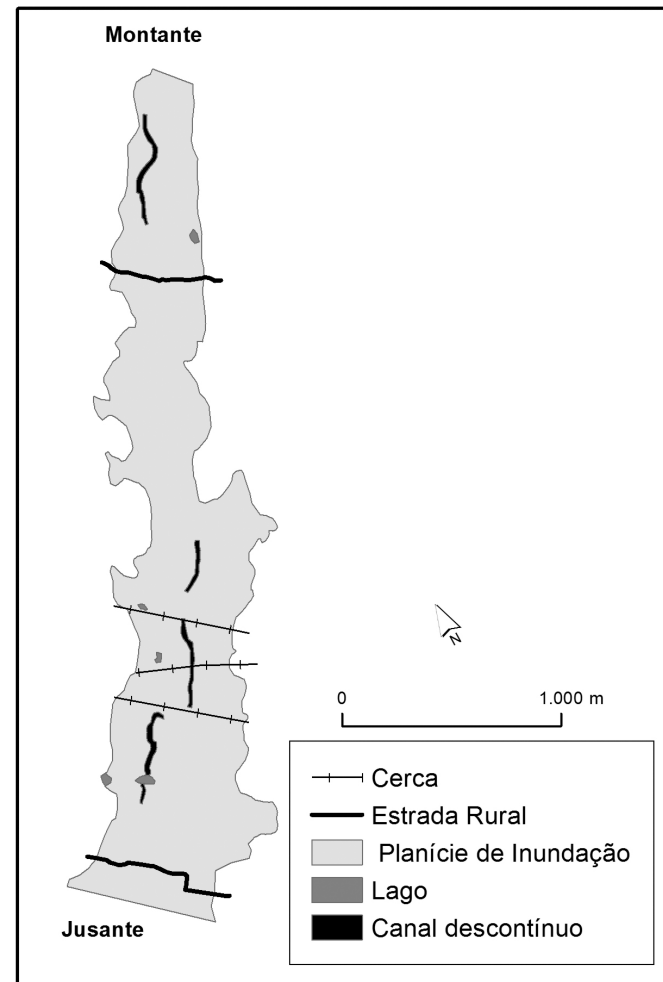

\begin{tabular}{|c|c|}
\hline \multicolumn{2}{|c|}{$\begin{array}{l}\text { MATRIZ DE ESTILOS FLUVIAIS - CANAL } \\
\text { DESCONTÍNUO ARENOSO }\end{array}$} \\
\hline \multicolumn{2}{|r|}{ CARACTERISTICAS FLUVIAIS } \\
\hline $\begin{array}{l}\text { Configuração } \\
\text { do Vale }\end{array}$ & Não confinado \\
\hline $\begin{array}{l}\text { Configuração } \\
\text { do canal }\end{array}$ & $\begin{array}{l}\text { Fundo de vale irregular preenchido de } \\
\text { sedimento, com a presença de } \\
\text { entrincheiramento descontínuo do canal, como } \\
\text { também a presença de áreas alagadas (poças, } \\
\text { lagos, barragens). }\end{array}$ \\
\hline $\begin{array}{l}\text { Textura de } \\
\text { Materiais de } \\
\text { Leito }\end{array}$ & $\begin{array}{l}\text { Preenchimento do fundo de vale, planície de } \\
\text { inundação, areno-argiloso. Nas áreas onde há o } \\
\text { canal entrincheirado há o predominio de leito } \\
\text { arenoso. Já nas áreas alagadas há a } \\
\text { predominância de textura argilosa. }\end{array}$ \\
\hline $\begin{array}{l}\text { Unidades } \\
\text { Geomórficas }\end{array}$ & $\begin{array}{l}\text { Geometria do Canal: canal descontínuo e } \\
\text { lateralmente e verticalmente irregular, } \\
\text { localização e migração dos canais } \\
\text { descontinuos estão ligados a variação do } \\
\text { estágio de alagamento a jusante. }\end{array}$ \\
\hline & $F$ \\
\hline
\end{tabular}

- Nenhuma forma diferenciada Formas fora do canal:

- Planície de inundação contínua com a presença de áreas alagadas, e canais tributários aprisionados.

Vegetação Apresenta duas configurações diferentes, na Associada área semiárida há a presença de vegetação de caatinga, árvores exóticas e pasto; nas áreas subúmidas há a presença de árvores isoladas, pasto e cana-de-açúcar.

\section{COMPORTAMENTO DO RIO}

Baixa Vazão Ausência de fluxo, presença de água nas áreas alagadas e em subsuperficie.

Média Vazão Presença de fluxo nos trechos com canais entrincheirados e áreas alagadas e saturação da planície de inundação. Aumento no fluxo de subsuperficie.

Alta Vazão Fluxo preenchendo todo o fundo de vale, com deposição de sedimentos na planície de inundação e em fluxos extremos o retrabalhamento do sedimento da planície de inundação.

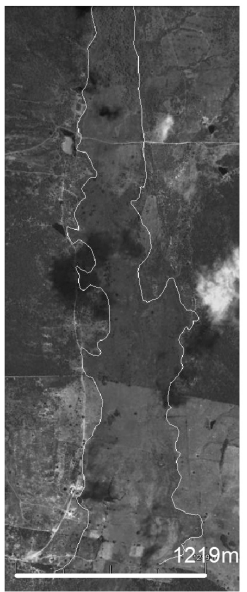

Sistema de Coordenada Geográfica DATUM: WGS 84

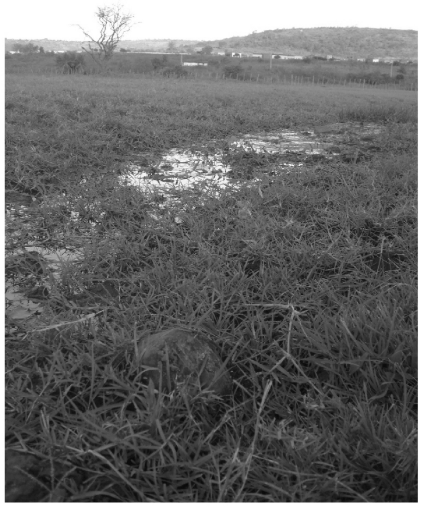

\section{CONTROLES}

\begin{tabular}{l|l}
\hline Bacia a & Áreas com alta produção de sedimento e
\end{tabular} Montante transporte eficiente. Ou áreas de canal preenchido em trechos submetidos a processos de preenchimento e entrincheiramento.

Unidade de Áreas pedimentares ou com caracteristicas Paisagem pedimentares a montante de áreas com retenção de sedimento e/ou soerguimento do nível de base.

Zona Zona de deposição e/ou retrabalhamento com Processual controle antrópico ou estrutural.

Morfologia Vales com encostas suaves, baixa sinuosidade do Vale com largura chegando a 500 metros.

Declive do $\quad$ Baixo gradiente, com áreas planas.

Vale

Competência Transporte de sedimentos mais finos em \begin{tabular}{l|l} 
do fluxo & suspensão, em eventos extremos pode haver o
\end{tabular} retrabalhamento do material da planície de inundação.

Intervenção Nos trechos semiáridos há a presença de pasto, Antrópica cercas e estradas de terra cortando o vale, escavação do leito para armazenamento de água. Na área subúmida há a plantações de pasto e cana-de-açúcar, cercas e poços amazonas.

Fig. 8 - Estilo fluvial Canal Descontínuo Arenoso.

Fig. 8 - Discontinuous Sand Bed Channel. 


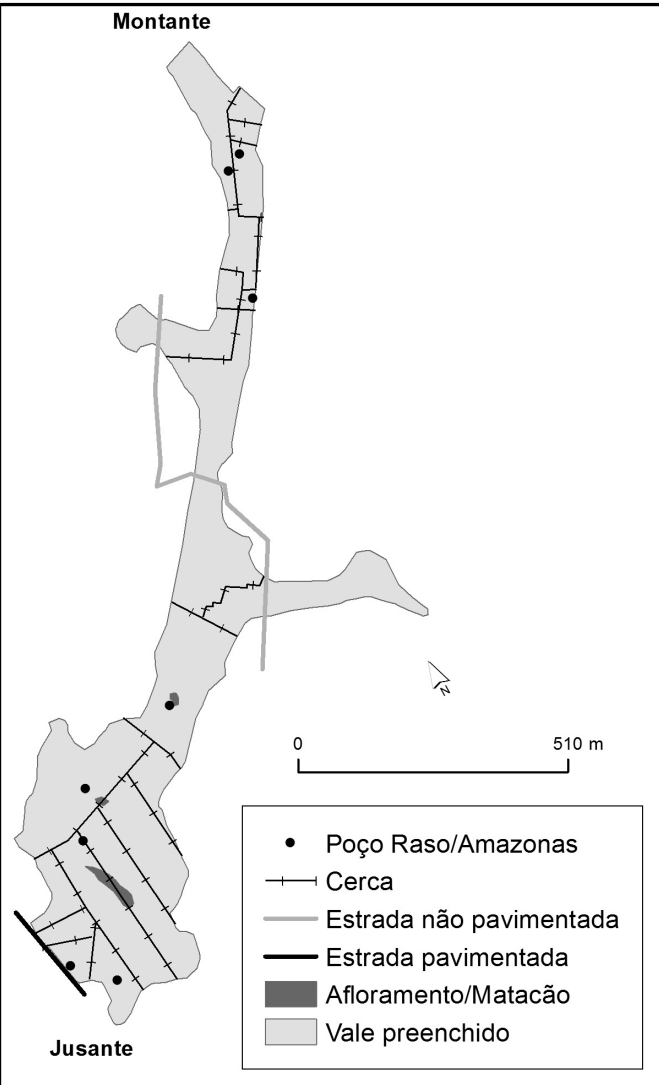

Sistema de Coordenada Geográfica DATUM: WGS 84
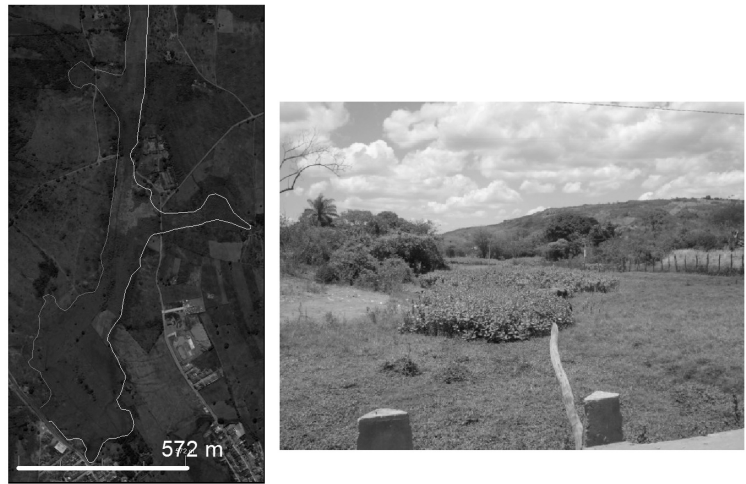

\begin{tabular}{|c|c|}
\hline $\begin{array}{r}\text { MATRI } \\
\text { PR }\end{array}$ & $\begin{array}{l}\text { Z DE ESTILOS FLUVIAIS - VALE } \\
\text { REENCHIDO CONSERVADO }\end{array}$ \\
\hline \multicolumn{2}{|r|}{ CARACTERISTICAS FLUVIAIS } \\
\hline $\begin{array}{l}\text { Configuração } \\
\text { do Vale }\end{array}$ & Não confinado \\
\hline $\begin{array}{l}\text { Configuração } \\
\text { do canal }\end{array}$ & $\begin{array}{l}\text { Fundo de vale irregular, totalmente } \\
\text { preenchido por sedimento. }\end{array}$ \\
\hline $\begin{array}{l}\text { Textura de } \\
\text { Materiais de } \\
\text { Leito }\end{array}$ & $\begin{array}{l}\text { Textura argilo-arenosa, com blocos, } \\
\text { matacões e afloramentos ocasionais. }\end{array}$ \\
\hline \multirow[t]{2}{*}{$\begin{array}{l}\text { Unidades } \\
\text { Geomórficas }\end{array}$} & $\begin{array}{l}\text { Geometria do Canal: não existe canal, há a } \\
\text { presença de áreas rebaixadas alagadas. }\end{array}$ \\
\hline & $\begin{array}{l}\text { Formas associadas a planície de inundação: } \\
\text { - Fundo de vale preenchido: planície de } \\
\text { inundação preenche toda área do fundo } \\
\text { de vale, com textura } \\
\text { predominantemente argilo-arenosa. } \\
\text { - Afloramento rochosos: alguns pontos } \\
\text { onde o substrato rochoso se eleva acima } \\
\text { do nível da planície. } \\
\text { - Área alagadas: áreas rebaixadas dentro } \\
\text { da planície de inundação, que } \\
\text { permanecem com água constantemente. } \\
\text { Pode ter gênese antrópica ou natural. }\end{array}$ \\
\hline $\begin{array}{l}\text { Vegetação } \\
\text { Associada }\end{array}$ & $\begin{array}{l}\text { Completa retirada da vegetação natural, } \\
\text { plantação predominante de pasto, e } \\
\text { plantação de cana-de-açúcar controlada pela } \\
\text { temporalidade das cheias. }\end{array}$ \\
\hline & OMPORTAMENTO DO RIO \\
\hline
\end{tabular}

Baixa Vazão Ausência de Fluxo, presença de água em subsuperfície e depressões.

Média Vazão Saturação da planície de inundação e nível máximo de água nas depressões. O fluxo ocorre em subsuperfície

\begin{tabular}{l|l}
\hline Alta Vazão & O fluxo de água corre acima do nível de
\end{tabular} sedimentação da planície, preenchendo todo o fundo de vale, e em eventos extremos remobilizando os sedimentos da planície.

\begin{tabular}{|c|c|}
\hline \multicolumn{2}{|r|}{ CONTROLES } \\
\hline $\begin{array}{l}\text { Bacia a } \\
\text { Montante }\end{array}$ & $\begin{array}{l}\text { Áreas com forte produção de sedimentos } \\
\text { e/ou com eficiente transporte }\end{array}$ \\
\hline $\begin{array}{l}\text { Unidade de } \\
\text { Paisagem }\end{array}$ & $\begin{array}{l}\text { Zonas planas com forte retenção de } \\
\text { sedimentos a jusante. }\end{array}$ \\
\hline $\begin{array}{l}\text { Zona } \\
\text { Processual }\end{array}$ & Zona de acumulação de sedimentos. \\
\hline $\begin{array}{l}\text { Morfologia } \\
\text { do Vale }\end{array}$ & Vales largos com baixa declividade. \\
\hline $\begin{array}{l}\text { Declive do } \\
\text { Vale }\end{array}$ & $\begin{array}{l}\text { Gradiente baixo, próximo a superfícies } \\
\text { planas. }\end{array}$ \\
\hline $\begin{array}{l}\text { Competência } \\
\text { do fluxo }\end{array}$ & $\begin{array}{l}\text { Baixa competência de transporte, } \\
\text { normalmente o transporte fica restrito a } \\
\text { eventos de alta magnitude, onde há o } \\
\text { retrabalhamento dos sedimentos das } \\
\text { camadas superiores. }\end{array}$ \\
\hline $\begin{array}{l}\text { Intervenção } \\
\text { Antrópica }\end{array}$ & $\begin{array}{l}\text { Retirada da vegetação do vale, plantio de } \\
\text { pasto e cana-de-açúcar, instalação de poços } \\
\text { amazonas. Presença de estradas não } \\
\text { pavimentadas cortando o vale, como } \\
\text { também pontes de estradas pavimentadas. }\end{array}$ \\
\hline
\end{tabular}

Fig. 9 - Estilo fluvial Vale Preenchido Conservado.

Fig. 9 - Intact Valley Fill River Style. 
Os trechos classificados como Leques Fluviais são encontrados em dois contextos diferentes, um a partir da diminuição repentina da declividade do perfil longitudinal, como também em alguns trechos onde a diminuição é gradual, mas existe a jusante a elevação do nível de base local, como o caso de barramento totais (barragens) ou parciais (estradas e/ou pontes mal dimensionadas), e a presença de largos trechos de canais preenchidos.

Em ambos os casos há a transição entre um canal confinado até um fundo de vale preenchido, sem presença de canal contínuo, podendo haver incisões curtas e temporárias no preenchimento sedimentar. Apresenta assim características semelhantes tanto aos canais confinados como aos canais preenchidos, posteriormente detalhados. Eles foram nomeados como leque fluvial pela forma no trecho não confinado, sendo caracterizado pelos depósitos sedimentarem em forma de leque, e sendo formado pelo fluxo em pulsos de sedimentos (principal característica da área ligado ao comportamento intermitente dos canais).

Os Canais Descontínuos Arenosos apresentam alta incidência na bacia, estando relacionados com vales largos de baixa declividade e baixo gradiente longitudinal. Eles ocorrem predominantemente na zona inundável, contudo em alguns pontos onde há barramentos a jusante, eles também ocorrem na unidade de paisagem de Pedimento. Ocorrem em fundos de vale irregulares preenchidos de sedimentos arenosos formando uma planície de inundação contínua, inclusive com depressões na superfície da planície de inundação formando áreas alagadas/alagadiças. O canal apresenta um entrincheiramento descontínuo, com instabilidade vertical e lateral dos trechos entrincheirados. Na baixa vazão há a presença de água em subsuperfície e nas áreas alagadas, e na alta vazão o fluxo preenche todo o fundo de vale por cima no nível da planície de inundação depositando sedimentos e, em casos extremos, retrabalhando os sedimentos. $\mathrm{Na}$ área de pedimento o impacto é a partir da pecuária, utilizando pasto natural, estradas e cercas cortando a planície de inundação e escavação do leito para obtenção/armazenamento de água. Na zona inundável a vegetação nativa foi retirada para a plantação de pasto artificial ou cana-de-açúcar, com cercas e poços rasos para a obtenção de água.

Por fim, os trechos de Vale Preenchido Conservado são caracterizados por fundos irregulares e largos, completamente preenchidos sem a presença de entrincheiramento de canal. Apresentam baixa declividade tanto no perfil transversal como no perfil longitudinal (normalmente com a presença de irregularidades). Caracterizam-se pela predominância do preenchimento sedimentar com maior presença de silte e argila, pela presença de áreas alagadas, e ainda pela presença isolada de matacões e afloramentos rochosos no leito. Apresentam comportamento de fluxo e tipos de uso semelhantes aos Canais Descontínuos Arenosos, normalmente estando a montante desses trechos.

Avaliando como um todos os diversos Estilos Fluviais identificados para a bacia, observa-se a presença das chamadas cut-and-fill landscapes, paisagens de incisão e preenchimento, ou seja, trechos fluviais nos quais alternam fases de preenchimento aluvial dos vales com fases de incisão vertical do preenchimento aluvial. A fase de preenchimento é controlada, normalmente, pela baixa capacidade erosiva dos fluxos, podendo estar rela- 
cionada com fluxos em pulsos, exemplo da dinâmica semiárida/sub-úmida na área analisada; eventos extremos podem gerar incisões nas áreas preenchidas, contudo caso não haja realmente uma mudança na dinâmica hidrológica com o aumento consistente nos fluxos, os eventos de baixa magnitude levam novamente ao preenchimento da incisão.

Essa dinâmica pode ser observada claramente entre os anos de 2009 e 2013, onde no ano de 2010 houve eventos superiores a $80 \mathrm{~mm} / \mathrm{dia}$, e nos anos subsequentes foram anos secos com predominância de eventos de baixa magnitude. Apenas para ilustrar as diferenças de precipitação anual, enquanto o biênio 2009/2010 teve uma média de $923 \mathrm{~mm} /$ ano, o biênio 2012/2013 teve uma média de precipitação de $386 / \mathrm{mm} /$ ano; sendo que a média para o posto é de cerca de $750 \mathrm{~mm} /$ ano. As repercussões desses eventos podem ser vistas na sequência de imagens de satélite de um trecho de vale preenchido conservado (fig. 10). O mosaico mostra 4 diferentes imagens de uma mesma área de um Vale Preenchido Conservado; inicialmente, em 2009, houve alguns eventos de distúrbio que geraram uma leve incisão inicial, na imagem de 2010 nota-se que após eventos de alta magnitude as incisões se aprofundam e aumentam em extensão. Após 2010 a região teve anos de menor precipitação e menos incidência de eventos de alta magnitude, sendo predominantes os eventos de baixa magnitude; isto gerou o progressivo preenchimento do canal, o que pode ser visto nas imagens de 2013, em especial na última imagem onde a incisão foi completamente preenchida. De forma geral, esse processo de incisão-preenchimento pode ocorrer nos outros estilos de vale preenchido, como é o caso dos canais descontínuos arenosos.

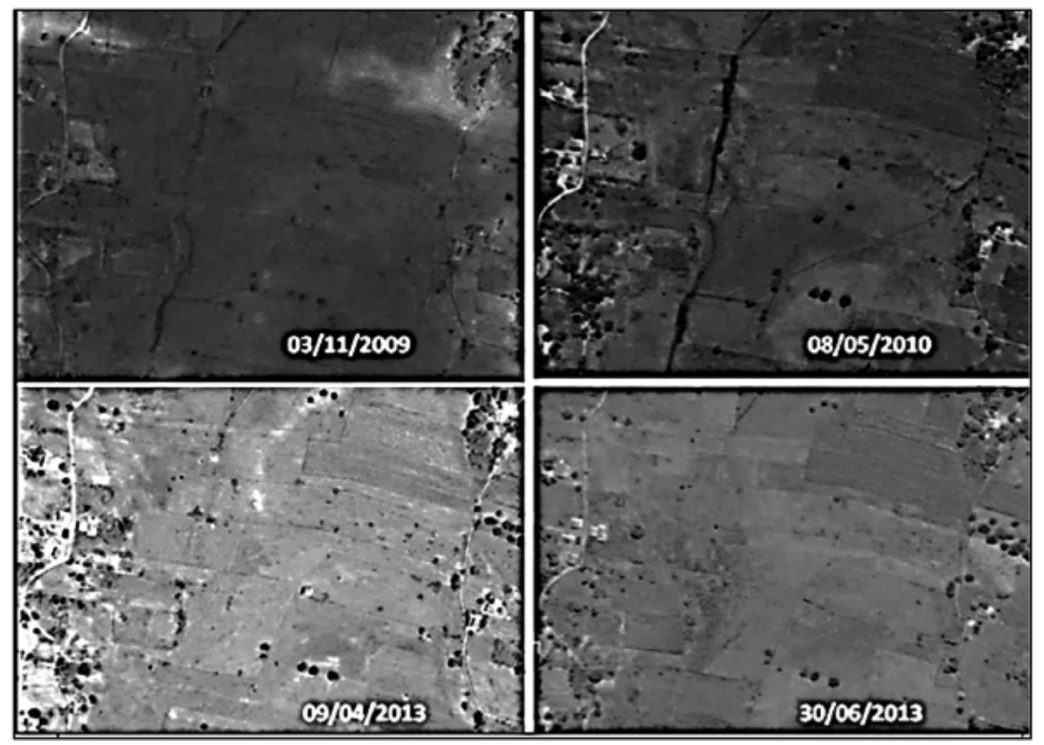

Fonte: Imagens QUIKBIRD

Fig. 10 - Processo de incisão e preenchimento (ver seta) em vale aluvial.

Fig. 10 - Cut-and-fill process (see arrow) of in alluvial valley. 
Os três estilos que se enquadram na dinâmica de incisão e preenchimento são os de Vale Preenchido Conservado, Canal Descontínuo Arenoso e no trecho de extravasamento de fluxo no estilo de Leque Fluvial. Como os fluxos de alta capacidade erosiva apresentam baixa periodicidade [segundo Souza (2014) a recorrência dos eventos extremos para a bacia são de 7,5 anos para a estação de Serra Tallhada (416 m de altitude) e 5,25 anos para a estação de Triunfo ( $1030 \mathrm{~m}$ de altitude)], os processos de preenchimento são predominantes, não ocorrendo, assim, canais contínuos sobre coberturas aluviais. É importante destacar que esses ambientes apresentam alta sensitividade, ou seja, maior propensão a apresentar respostas sensíveis/reconhecíveis a alguma mudança ambiental, onde mudanças no regime hidrológico, naturais e especialmente antrópicas, podem gerar modificações severas na estrutura do estilo fluvial, incluindo a modificação de estilos de forma geral. Nanson \& Croke (1992) afirmam que ambientes semelhantes ao encontrado na bacia do Saco, com textura não coesa e alta presença de matéria orgânica, tendem à erosão ligada à ocupação antrópica, devido ao aumento do escoamento gerado pela retirada da vegetação nativa.

\section{CONCLUSÕES}

A bacia do riacho do Saco tem um forte controle estrutural relativamente à diferenciação de determinados estilos fluviais como, por exemplo, os Canais em Garganta, com todos os trechos desse estilo localizados na região de escarpa de falha. Contudo, o que se destaca é o controle antrópico na evolução/transformação/criação de estilos fluviais, em especial a partir da elevação do nível de base local devido ao barramento total ou parcial dos cursos fluviais, como é o caso de alguns dos trechos de Leque Fluvial e Canais Arenosos Descontínuos. A formação de Canais de Voçoroca também pode resultar, ou ser influenciada, pela modificação antrópica, especialmente a partir da cobertura vegetal e/ ou pela mudança dos tipos de uso do solo, gerando desequilíbrio. Em relação aos estilos fluviais de vales preenchidos, eles podem sofrer alterações morfológicas temporárias devido a variabilidades hidrológicas, sem, no entanto, caracterizar uma mudança no estilo fluvial. Esse processo faz parte do comportamento usual desse estilo fluvial alternando em anos secos, preenchimento, e chuvosos, incisão, especificamente para eventos extremos.

A evolução recente do transporte de sedimentos na bacia do riacho do Saco tem sido dominada por processos de agradação e estocagem de sedimentos em lagos de açudes, bem como em preenchimentos de fundo de vale a montante dos açudes e em trechos planos longos com vales preenchidos. Esses trechos isolam as áreas a montante dos mesmos, dificultando o transporte de sedimento de fundo, aonde apesar do grande volume de escoamento que chega a esses locais, como é o exemplo das áreas planas e alagadas do centro de Santa Cruz da Baixa Verde, a energia é dissipada devido à declividade próxima de zero, depositando os sedimentos carreados das áreas a montante. Esse comportamento se repete em vários ambientes semelhantes pelo mundo como é o caso de áreas secas na 
Austrália (Graf, 1994; Fryirs \& Brierley, 1999), Espanha (Harvey, 2012), e EUA (Phillips \& Sllattery, 2006); sendo controlado por mudanças e flutuações do nível de base local, como acontece nas áreas de barragem, além das baixas declividades.

A aplicação da metodologia dos estilos fluviais proporcionou a construção de um inventário sobre as características e comportamento, em diferentes cenários, de diferentes trechos fluviais, cada qual apresentando um arranjo estrutural e processual diferenciado. Tal arcabouço é indispensável a programas de preservação/conservação ambiental, planeamento ambiental, gestão de recursos hídricos, como, também, programas de recuperação e reabilitação fluvial. Uma das aplicações possíveis seria, a partir do melhor entendimento das características e localização das áreas de vale aluvial, avaliar o potencial dessas áreas no armazenamento de água subsuperficial. Tais áreas estão diretamente ligadas aos estilos fluviais de preenchimento de vale. A partir dessas informações e da análise da sua dinâmica hidrológica, seria possível uma melhor gestão da água em subsuperfície nos períodos secos, recurso essencial para a região, principalmente para o município de Santa Cruz da Baixa Verde, no qual são utilizados poços rasos na obtenção da água. Desse modo, por exemplo, seriam áreas prioritárias para conservação e monitorização dos recursos hídricos.

\section{REFERÊNCIAS BIBLIOGRÁFICAS}

Brierley, G., Fryirs, K., Outht, D. \& Massey, C. (2002). Application of the River Styles framework as a basis for river management in New South Wales, Australia. Applied Geography, 22, 91-122.

Brierley, G. \& Fryirs, K. (2000). River Styles, a geomorphic approach to catchment characterization: implications for river rehabilitation in Bega Catchment, New South Wales, Australia. Environmental Management, 25 (6), 661-679.

Brierley, G. \& Fryirs, K. A. (2005). Geomorphology and River Management: applications of the river styles framework. Oxford: Blackwell Publications, Oxford.

Campos, J. N. B., Vieira Neto, J. F. \& Martins, E. S. (1997). Vulnerabilidade de sistemas hídricos: um estudo de caso. Revista Brasileira de Recursos Hídricos, 2 (2), 21-44.

Cirilo, J. A. G., Abreu, H. F. G., Costa, M. R., Goldemberg, D., Costa, W. D., Baltar, A. M. \& Azevedo, L. G. T. (2003). Soluções para o suprimento de água de comunidades rurais difusas no semi-árido brasileiro: avaliação de barragens subterrâneas. Revista Brasileira de Recursos Hídricos, 8 (4), 5-24.
Corrêa, A. C. B., Tavares, B. A. C., Monteiro, K. A., Cavalcanti, L. C. S. \& Lira, D. R. (2010). Megageomorfologia e morfoestrutura do Planalto da Borborema. Revista do Instituto Geológico, 31 (1/2), 35-52.

Corrêa, A. C. B., Maciel, F., Souza, J. O. P., Azambuja, R. N. \& Araújo, M. S. B. (2009). Estilos fluviais de uma bacia de drenagem no submédio São Francisco. Revista de Geografia - Recife, 26 (1), 181-215 .

Fryirs, K. \& Brierley, G. (2005). Practical application of the River Styles ${ }^{\oplus}$ framework as a tool for catchment-wide river management: A case study from Bega catchment, New South Wales, Australia. ebook: site: http://www.riverstyles.com/ebook.php

Fryirs, K. \& Brierley, G. J. (2009). Naturalness and place in River Rehabilitation. Ecology and Society, 14 (1), 1:10.

Harvey, A. M. (2012). The coupling status of alluvial fans and debris cones: a review and synthesis. Earth Surface Process and Landforms, 37, 64-76.

Molinas, P. A. (1996). A gestão dos recursos hídricos no semi-árido nordestino: a experiência cearense. Revista Brasileira de Recursos Hídricos, 1, 67-88. 
Molion, L. \& Bernardo, S. (2002). Uma Revisão Dinâmica das chuvas sobre o Nordeste do Brasil. Revista Brasileira de Meteorologia, 17 (1), 1-20.

Nanson, G. C. \& Croke, J. C. (1992). A genetic classification of floodplains. Geomorphology, 4, 459-486

Peixoto, M. N. O., Cesário, F. V., Pimentel, M. L., Mello, E. V. \& Oliveira, D. F. P. (2010). Identificação de estilos de rios em bacias de drenagem inseridas em compartimentos de colinas - médio vale do rio Paraíba do Sul (RJ). Revista de Geografia - Recife, Volume Especial - VIII SINAGEO, 347-362

Phillips, J. D. \& Slattery, M. (2006). Sediment storage, sea level, and sediment delivery to the ocean by coastal plain rivers. Progress in Physical Geography, 30 (4), 513-530.
Souza, J. O. P. \& Corrêa, A. C. B. (2012). Sistema fluvial e planejamento local no semiárido. Mercator, 11, 149-168.

Souza, J. O. P. (2014). Modelos de evolução da dinâmica fluvial em ambiente semiárido - bacia do açude dosaco, Serra Talhada, Pernambuco. Tese de doutoramento - Universidade Federal de Pernambuco, CFCH. Programa de Pós-Graduação em Geografia, Recife.

Vieira, V. P. P. B. (1996). Recursos hídricos e o desenvolvimento sustentável do semi-árido nordestino. Revista Brasileira de Recursos Hídricos, 1, 89-107.

Vieira, V. P. P. B. (2003). Desafios da gestão integrada de recursos hídricos no semi-árido. Revista Brasileira de Recursos Hídricos, 8 (2), 7-17. 